\title{
Effect of Extension Training on Technical Efficiency of Maize Farmers in Ogbomoso Agricultural Zone of Oyo State, Nigeria
}

\author{
Akintonde J. Oluwole ${ }^{1}$, Akintaro O. Segun ${ }^{1}$, Rahman S. Bayonle ${ }^{1}$, \\ Bamidele B. Samuel ${ }^{2}$, Oladosu I. Oladeji ${ }^{1}$ \\ ${ }^{1}$ Department of Agricultural Extension and Rural Development, PMB 4000, Ladoke Akintola University of \\ Technology, Ogbomoso, Oyo State, Nigeria. \\ ${ }^{2}$ Department of Agricultural Extension and Management, Federal College of Agriculture, P.M.B. 5029, Moore \\ Plantation, Ibadan, Oyo State, Nigeria.
}

Corresponding Author: Akintonde J. Oluwole

\section{ABSTRACT}

The efficiency of any entrepreneur is a function of personal production skill, knowledge and experience acquired over time and exposure via training in the field of his or her enterprise focus. It is on this premise that this study examined the effect of extension training on technical efficiency of maize farmers in Ogbomoso Agricultural Zone, Oyo State, Nigeria. Multistage sampling procedure was adopted for the selection of One-hundred and Eighty-One (181) maize farmers, while structured and validated interview schedule was used to obtain necessary information from the sampled respondents. Data collected were analyzed using both descriptive and inferential statistical tools. The mean age of sampled farmers was 48 years and majority $(80.1 \%)$ of the farmers was male. The farmers with extension contact have access to different extension trainings on maize production in the study area. The average household sizes were 7 and 8, with the average farm sizes of $1.423 \mathrm{ha}$ and 1.417 ha for both contact and non-contact maize farmers respectively. Those farmers with extension contact were found to be technically efficient than non-contact farmers. Significant relationship existed between some selected socio-economic characteristics of both sampled maize farmers and their maize output. The study therefore suggests the need to create more awareness on the roles of extension services on crop production among farmers and the authorities concern with extension service
\end{abstract}

delivery should improve on the frequency of extension contact in order to encourage farmers' participation in extension activities in the study area and rural communities in Nigeria at large.

Key Words: Extension training, technical efficiency, contact and non-contact maize farmers

\section{INTRODUCTION}

The strength and expansion of agricultural production still rely upon provision of required, relevant and appropriate technologies through the extension and support services. A technical efficient farmer is the one who has the ability to attain maximum level of output from a given bundle of input at least costs. The efficiency of any farmer is subject to production skills he/she possess, experience and exposure and knowledge gained via extension training. The main objective of agricultural extension services is to encourage farmers by improving their skill, attitude and knowledge in order to be technically efficient in their various areas of agricultural production. The objective of any national agricultural extension is to improve farmers' output by adopting new or improved farming technologies, practices and methods. Traditionally, farming technologies reach the farmers via extension personnel, who have the responsibility to 
ensure that the desired technology is appreciated and use by the farmers ${ }^{[7]}$. In Nigeria, the current agricultural extension approach Farmers' Field School (FFS) which still operates with the Training and Visit $(\mathrm{T} \& \mathrm{~V})$ approach. The major aim of $\mathrm{T} \& \mathrm{~V}$ system is to build up a professional extension service that is capable of assisting farmers in increasing production and raising their standard of living and provide appropriate support for agricultural development. The system involves the systematic application of well-known management principles with a view to professionalizing the extension services.

Efficiency is often used synonymously with productivity, which relates output to input. In agriculture, the analysis of efficiency is generally associated with the possibility of farm production to attain optimal level of output from a given bundle of input at least cost. The crucial role of efficiency in increasing agricultural output has been widely recognized by researchers and policy makers alike. It is no surprise that considerable effort has been devoted to the analysis of farm level of efficiency in developing countries. An underline premise behind this work is that if farmers are not making efficient use of existing technology then efforts designed to improve efficiency would be more cost effective than introducing new technologies as a means of increasing agricultural output [4]. Extension assists farmers by increasing their awareness of improved agricultural technology and improving their decisionmaking skills. It also aims at improving agricultural production by enhancing the knowledge, attitude and skill of the farm population, thus for the rural farmers to be more efficient, the required knowledge, skill and attitude needed to make proper use of new technologies can be enhanced through the extension training. It is on this note that this paper established the effect of extension training on technical efficiency of maize farmers in Ogbomoso Agricultural zone of Oyo State, Nigeria. Specifically, the study described the socioeconomic characteristics of the maize farmers; identified the extension training recommendations/level of usage among the respondents and determined the technical efficiency of maize farmers with extension contact and nonextension contact in the study area.

\section{METHODOLOGY}

This study was carried out in Ogbomoso Agricultural Zone of Oyo State. The zone is one of the four Agricultural zones in Oyo State. Ogbomoso Agricultural Zone comprises of five (LGAs). Multistage sampling procedure was adopted for this study. Firstly, purposive sampling technique was employed in the selection of three LGAs which includes Surulere, Ogo-Oluwa, and Oriire LGAs respectively due to their rurality in nature. During the second stage, one percent $(1 \%)$ number of villages was considered from the list of registered villages in the selected LGAs. Thereafter, the use of random number table was employed in the selection of five (5) villages from Oriire LGA, three (3) villages from Surulere LGA, and two (2) villages from Ogo-Oluwa LGA respectively, which amounted to a total of ten (10) villages and fifteen percent $(15 \%=111)$ of the registered maize farmers were randomly selected among the maize farmers that have contact with extension service and similar proportion of 70 maize farmers without extension contact were equally randomly selected. Both selections amounted to 181 respondents that constituted the sample size of the study. Both descriptive (frequency counts, percentages, mean) and inferential (stochastic production frontier) statistical tools were employed to analyzed the collected data of the study.

\section{Model specification}

The stochastic frontier production function is stated as

$I_{n} Y_{i}=b_{0}+b i \operatorname{In} X_{1}+b_{2} \operatorname{In} X_{2}+b_{3} \operatorname{In} X_{3}+\ldots+$ $V_{i}-U_{i}$

In: denote the natural logarithm Efficiency function is stated as follow:

$Y=$ Output of maize $(\mathrm{kg})$ 
$X_{1}=$ Labour used (man days)

$X_{2}=$ Farm size (ha)

$X_{3}=$ Seeds quantity $(\mathrm{kg})$

$X_{4}=$ Quantity of fertilizer $(\mathrm{kg})$

$\mathrm{X}_{5}=$ Herbicide quantity (litres)

Where inefficiency function is also stated as

$U i=\mathrm{a}_{0}+\mathrm{a}_{i} z_{i} a_{2} z_{2}+\mathrm{a}_{3} z_{3}+\ldots$

Where

$\mathrm{Z}_{1}=$ Family size (number)

$\mathrm{Z}_{2}=$ Farming experience (years)

$Z_{3}=$ Frequency of extension contact (number)

$\mathrm{Z}_{4}=$ Educational level (year in school)

$Z_{5}=$ Number of types of extension channel (number of types)

$\mathrm{V}_{\mathrm{i}}=$ Two sided normally distributed random error

$\mathrm{U}_{\mathrm{i}}=$ One sided inefficiency component with half normal distribution.

\section{RESULTS AND DISCUSSION Socio-economic Characteristics}

Table1 revealed the mean age of farmers to be 47 years and 46 years for both farmers with extension contact and nonextension contact respectively. The mean age of maize farmers suggests that maize farming is dominated by the older farmers in the study area. This is expected to have a significant effect on their productivity and this is in line with the study of ${ }^{[4]}$, which observed that older farmers were less efficient than the younger ones. Majority of both farmers were male $(80.2 \%$ of contact and $80.0 \%$ of non-extension contact farmers). This implies that males were found to be more involved in maize production than their female counterparts. The significant margin $(80.1 \%$ male to $19.9 \%$ female) in their pooled percentage also proofed that male were more involved in male production than female counterparts in the study area, which may due to energy requirements of the farm enterprise in question. This is supported by ${ }^{[5]}$ that, an indication that the traditionally recognized "visible" human input in the agricultural sector is the male contribution.

Also, the result in table 3 indicates that higher percent of both farmers were illiterate $(53.2 \%$ contact and $48.6 \%$ noncontact farmers). From the pooled percentage, it implies that majority $(51.4 \%)$ of the sampled maize farmers do not have formal education. This may be due to the individual farmer's background and this is expected to have some influence on their level of receptivity of the extension training and information services provided. This is in line with a study by ${ }^{[10]}$ that farmers with more years of school tended to be more technically efficient than the farmers with no education. The average household sizes were 7 and 8 . It is high for non-contact farmers. The result revealed that the main reason for maintaining large household sizes is to ensure adequate supply of family labour for maize production activities. This is in line with ${ }^{[2]}$ that large families appeared to be more efficient than small families.

Table 1: Frequency distribution of respondents by personal characteristics

\begin{tabular}{|c|c|c|c|}
\hline \multicolumn{4}{|c|}{ Frequency (Percentage) } \\
\hline $\begin{array}{l}\text { Personal } \\
\text { Characteristics }\end{array}$ & Contact & $\begin{array}{l}\text { Non- } \\
\text { Contact }\end{array}$ & Pooled \\
\hline Age (Years) & & & \\
\hline $30-40$ & $27(24.3)$ & 21(30.0) & $48(26.5)$ \\
\hline $41-50$ & $28(43.2)$ & 3347.1) & $81(44.8)$ \\
\hline $51-60$ & $29(26.1)$ & $12(17.1)$ & $40(22.1)$ \\
\hline $61-70$ & $7(6.3)$ & $4(5.7)$ & $12(6.6)$ \\
\hline Mean & 47 & 46 & 47 \\
\hline Sex & & & \\
\hline Male & $89(80.2)$ & $56(80.0)$ & $145(80.1)$ \\
\hline Female & $22(19.8)$ & $14(20.0)$ & $36(19.9)$ \\
\hline Educational Level & & & \\
\hline No Formal & $59(53.2)$ & $34(48.6)$ & $93(51.4)$ \\
\hline Primary School & $20(18.0)$ & $12(17.1)$ & $22(17.7)$ \\
\hline Junior Sec School & $9(8.1)$ & $7(10.0)$ & $16(8.8)$ \\
\hline Senior Sec School & 21(18.9) & $13(18.6)$ & $34(18.8)$ \\
\hline Tertiary Education & $2(1.8)$ & $4(5.7)$ & $6(3.3)$ \\
\hline Marital Status & & & \\
\hline Married & 111(100.) & 70(100.) & 181(100.) \\
\hline Farming as Primary & & & \\
\hline Occupation & & & \\
\hline Yes & 104(93.7) & $64(91.4)$ & $168(92.8)$ \\
\hline No & $7(6.3)$ & $6(8.6)$ & $13(7.2)$ \\
\hline Family size & & & \\
\hline $1-5$ & $22(19.8)$ & $15(21.4)$ & $37(20.4)$ \\
\hline $6-10$ & $82(73.9)$ & $47(67.2)$ & $129(71.3)$ \\
\hline $11-15$ & $7(6.3)$ & $8(11.4)$ & $15(8.3)$ \\
\hline Mean & 7 & 8 & 7 \\
\hline
\end{tabular}

Again, majority (74.8\%) of the farmers who had extension contact were visited fortnightly by the extension agent, while $25.2 \%$ of the farmers received extension visit on monthly basis. The frequency of extension visit by extension agent may be due to willingness of fanners 
to receive extension information/messages from the extension agents. This is supported by $^{[5]}$ which stated that majority of the farmers know the extension agents, only a few used them as source of information, since most depend on friends/relatives and radio as their sources of agricultural information. The mean years of farming experience of both contact mid non-contact maize fanners (23 and 21) with their standard deviation of 9.367 (contact farmers) and 8.94 (non-contact farmers). This shows that a considerable proportion of both farmers in the sample had more than a decade of farming experience, which suggests that most people in the area must have started farming in their youth, and regards it as a way of life and this is expected to influence their maize output. This is supported by ${ }^{[9]}$ that the length of experience in farming is probably an indicator of a person's commitment to agriculture and also in line with a study by ${ }^{[2]}$ that farming experience contributes positively to production. The mean farm size of both contact maize farmers (1.423) and non-contact farmers (1.417). The average farm size differs between the contact and non-contact farmers (i.e. high for contact farmers). The difference in the size of farmland may be due to the capital availability and or need to cultivate other crops. This implies that all the sampled fanners cultivate maize under different sizes of land and the difference in the size of their maize farm may be due to the land ownership pattern, which affects the land usage in the study area.

\section{Extension training recommendations and level of usage}

Table 2 revealed the multiple responses from the farmers with extension contact in relation to extension training recommendations used and level of usage. For this objective, rating scale of high (3), moderate (2), low (1) and not at all (0). Thereafter, mean was computed and ranked accordingly to determine the level of usage of available extension recommendations among the maize farmers in the study area. It was revealed that all $(100.0 \%)$ of the maize farmers used all the identified extension training recommendations except very few $(8.1 \%)$ that declined to fertilizer application. On the level of usage, thinning had the highest weighted mean score $\left(\mathrm{WMS}=2.53\right.$ ) and ranked $1^{\text {st }}$, followed by planting of improved seeds $\left(\mathrm{WMS}=2.51 / 2^{\text {nd }}\right)$; seed protection (WMS $=2.41 / 3^{\text {rd }}$; use of chemicals $\left(\mathrm{WMS}=2.39 / 4^{\text {th }}\right)$ respectively, while plant spacing $\left(\mathrm{WMS}=1.50 / 10^{\text {th }}\right.$ ) was ranked least. The result implies that all the maize famers sampled used all the identified extension training recommendations. The variation in the level of usage may be due to differences in their perception, years of experience/cultural syndrome (norm and belief) of the farmers with respect to maize production.

\begin{tabular}{|c|c|c|c|c|c|c|}
\hline \multirow[t]{2}{*}{ Extension recommendations } & \multicolumn{6}{|c|}{ Level of use } \\
\hline & High & Moderate & Low & Not at all & WMS & Rank \\
\hline Planting of improved seeds & $57(51.4)$ & $54(48.6)$ & - & - & 2.51 & $2^{\text {nd }}$ \\
\hline Plant spacing & - & $56(50.5)$ & $55(49.5)$ & - & 1.50 & $10^{\text {th }}$ \\
\hline Thinning & $59(55.2)$ & $52(46.8)$ & - & - & 2.53 & $1^{\text {st }}$ \\
\hline Use of chemicals & $43(38.7)$ & $68(61.3)$ & - & - & 2.39 & $4^{\text {th }}$ \\
\hline Seed protection & $46(41.4)$ & $65(58.6)$ & - & - & 2.41 & $3^{\text {rd }}$ \\
\hline Fertilizer application & $41(36.9)$ & $38(34.2)$ & $23(20.7)$ & $9(8.1)$ & 2.0 & $9^{\text {th }}$ \\
\hline Pest/diseases management & $34(30.6)$ & $49(44.1)$ & $28(25.2)$ & - & 2.05 & $7^{\text {th }}$ \\
\hline Weed control & $55(49.5)$ & $31(27.9)$ & $25(22.5)$ & - & 2.27 & $6^{\text {th }}$ \\
\hline Harvesting/storage & $38(34.2)$ & $40(36.0)$ & $33(29.7)$ & - & 2.05 & $7^{\text {th }}$ \\
\hline Processing & $54(48.6)$ & $43(38.7)$ & $14(12.6)$ & - & 2.36 & $5^{\text {th }}$ \\
\hline
\end{tabular}

Technical efficiency of the maize farmers with extension contact
Signs and significance of estimates of stochastic frontier production function (i.e. Cobb-Douglas frontier function type). 
The ordinary least square (OLS) (Model 1) and the maximum likelihood parameter estimates (MLE) (Model 2) of the stochastic production frontier models, which was specified as Cobb-Douglas frontier production function for both farmers with and without extension contact with their pooled are presented in Tables 3, 4 and 5 respectively. The coefficients of the variables are very important in discussing the results of the analyzed data. These coefficients represent percentage change in the dependent variable as a result of percentage change in the independent variables. This method of analysis is supported with prior studies ${ }^{[1,10]}$.

According to Table 3, for the farmers who have contact with extension training, the significant variables includes labour used (1\%), farm size (1\%), seed quantity used (1\%), herbicide quantity (1\%), frequency of extension contact $(10 \%)$ and types of channel $(5 \%)$, while the other variables like quantity of fertilizer used, family size, farming experience and educational level were all not significant at all known levels of significance. By implication, the above findings revealed that the major inputs which determined the output of maize farmers were the labour used, farm size, quantity of seed, quantity of herbicide used, frequency of extension contact, and number of types of extension channel used.

Quantity of herbicide used had the highest coefficient, with a value of 0.8851 in the preferred model (model 2) and by implication the quantity of herbicide used appeared as the most important input which determined the output of the maize farmers with extension contact. In the preferred model (Model 2) for the maize farmers with extension contact, all the significant variables (labour used, farm size, quantity of seed used, quantity of herbicide used, frequency of contact, number of types of extension channel) carried positive signs. The economic implication of the signs is that any increase in any of the aforementioned variable would lead to increase in maize output of the farmers with access to extension training visa-vis. Negative coefficient on a variable might indicate an excessive utilization of such a variable. This is in line with a study by ${ }^{[6]}$ that the interaction between extension agents and contact farmers has generally had positive result as reflected in the greater increase in production experienced by contact farmers-compared to farmers who did not have direct contact with extension.

Table 3: Maximum likelihood estimates for the parameters of the stochastic frontier production function of maize farmers with extension contact

\begin{tabular}{|c|c|c|c|}
\hline Variable & Parameter & $\begin{array}{l}\text { Model } \\
2\end{array}$ & T-value \\
\hline \multicolumn{4}{|l|}{$\begin{array}{l}\text { General model } \\
\text { (production function) }\end{array}$} \\
\hline Constant & $\beta_{0}$ & 0.2136 & 23.0926 \\
\hline Labour used & $\beta_{1}$ & 0.1501 & $8.0616^{* * * *}$ \\
\hline Farm size & $\beta_{2}$ & 0.1491 & $4.4941 * * *$ \\
\hline Seed quantity used & $\beta_{3}$ & 0.4893 & $9.6794 * * *$ \\
\hline Fertilizer quantity & $\beta_{4}$ & 0.7501 & 0.0604 \\
\hline Herbicide quantity used & $\beta_{5}$ & 0.8851 & $7.1406 * * *$ \\
\hline $\begin{array}{l}\text { Inefficiency model } \\
\text { Constant }\end{array}$ & $\delta_{0}$ & 0.1173 & 1.3188 \\
\hline Family size & $\delta_{1}$ & -0.8835 & -0.4941 \\
\hline $\begin{array}{l}\text { Year of farming } \\
\text { experience }\end{array}$ & $\delta_{2}$ & 0.3466 & 0.5518 \\
\hline $\begin{array}{l}\text { Frequency of extension } \\
\text { contact }\end{array}$ & $\delta_{3}$ & 0.4285 & $1.8340^{*}$ \\
\hline Educational Level & $\delta_{4}$ & -0.1515 & -0.1495 \\
\hline $\begin{array}{l}\text { Number of types of } \\
\text { extension channel }\end{array}$ & $\delta_{5}$ & 0.5093 & $2.1391 * *$ \\
\hline \multicolumn{4}{|l|}{ Variance parameters } \\
\hline Sigma Squared & $\sigma^{2}$ & 0.3318 & \\
\hline Gamma & $\Gamma$ & 0.9855 & $6.0899 * *$ \\
\hline Log Likelihood Function & & 204.9 & $97.0127 *$ \\
\hline
\end{tabular}

The study also revealed the significant variables among the maize farmers without extension contact which include: labour (5\%), farm size (5\%), fertilizer quantity (1\%) and farming experience $(1 \%)$, while quantity of seed used, quantity of herbicide used, family size, and educational level were not significant at all known levels of significance. The implication of the above findings is that labour used, farm size; quantity of fertilizer used and farming experience contribute greatly to maize output of the maize farmers without access to extension training. Among the above four major significant input, farming experience has the highest coefficient with a value of 0.9287 in the preferred models (Model 2) 
and therefore, it appeared as the most limiting factor which determined maize output among the maize farmers without extension contact. In the preferred model, farming experience has a negative sign meaning that farmers without extension contact depend so much on their experience on maize production and this may invariably lead to decrease in maize output. This is because instead for them to search for new information and technology on maize production they only depend on their primitive and obsolete methods of maize production.

\section{Stochastic frontier production function of maize farmers without extension contact}

Table 4 shows the pool result of both the maize farmers with and without extension contact, the significant variable includes; labour (1\%), farm size (1\%), quantity of fertilizer used $(1 \%)$, fanning experience $(5 \%)$, frequency of extension contacts $(1 \%)$ and educational level $(1 \%)$. While other variables such as quantity of seed used, quantity of herbicide used, family size and number of types of extension channel used were not significant at known levels of significance. The implication of the above findings is that labour used, farm size, quantity of fertilizer used; farming experience, frequency of contact and educational level, all have positive effect on maize output of both maize farmers with and without extension contact. Among the above six significant variables (labour used, farm size, quantity of fertilizer used, farming experience, frequency of extension contacts and educational level), frequency of extension contact has the highest coefficient with a value of- 0.8718 in the preferred model (Model 2) and therefore, it existed as the direct production input which determined the maize output among the maize farmers in the study area. The variables with positive coefficient simply mean that any increase in any of such variables would lead to a direct increase in maize output of the maize farmers.
Table 4: Maximum likelihood estimates for the parameters of the stochastic frontier production function of maize farmers without extension contact

\begin{tabular}{|c|c|c|c|}
\hline Variable & Parameter & $\begin{array}{l}\text { Model } \\
2\end{array}$ & T-value \\
\hline \multicolumn{4}{|l|}{$\begin{array}{l}\text { General model } \\
\text { (production function) }\end{array}$} \\
\hline Constant & $\beta 0$ & -0.2077 & -10.0627 \\
\hline Labour used & $\beta 1$ & 0.1314 & $2.0413 * *$ \\
\hline Farm size & $\beta 2$ & 0.2262 & $2.3116^{* *}$ \\
\hline Seed quantity used & $\beta 3$ & -0.1582 & -0.8945 \\
\hline Fertilizer quantity & $\beta 4$ & 0.6716 & $5.8688 * * *$ \\
\hline Herbicide quantity used & $\beta 5$ & 0.1810 & 0.5338 \\
\hline $\begin{array}{l}\text { Inefficiency model } \\
\text { Constant }\end{array}$ & $\delta 0$ & 0.1113 & 0.9611 \\
\hline Family size & $\delta 1$ & 0.4904 & 0.3097 \\
\hline $\begin{array}{ll}\text { Year of farming } \\
\text { experience }\end{array}$ & $\delta 2$ & -0.9287 & $-2.127 * *$ \\
\hline $\begin{array}{l}\text { Frequency of extension } \\
\text { contact }\end{array}$ & $\delta 3$ & 0.0000 & 0.0000 \\
\hline Educational Level & $\delta 4$ & -0.3655 & -0.3851 \\
\hline $\begin{array}{l}\text { Number of types of } \\
\text { extension channel }\end{array}$ & $\delta 5$ & 0.0000 & 0.0000 \\
\hline Variance parameters & & 0.2712 & $3.9949 * * *$ \\
\hline Sigma Squared & $\sigma 2$ & 0.1658 & \\
\hline Gamma & $\Gamma$ & -0.2077 & -10.0627 \\
\hline Log Likelihood Function & & 0.1314 & $2.0413^{* *}$ \\
\hline
\end{tabular}

\section{Goodness of fit of the model}

The estimated sigma square $\left(\sigma^{2}\right)$ of the two categories of the maize farmers, that is $1 \%$ ) and 3.9949 (significant at $1 \%$ ) respectively while their pooled was 5.8356 (significant at $1 \%$ ). There is a clear variation in the values and all are large significant at the same level of significance. This indicates a good fit of the model and the correctness of the specified distributional assumptions. The result suggests that maize farmers with extension contact are technically efficient than those farmers without extension contact. The study is in line with ${ }^{[5]}$.

\section{Estimated gamma $(\gamma)$ parameter}

The estimated gamma $(\gamma)$ parameter of maize farmers with and without extension contact and their pooled are 0.97, 0.52 and 0.33 respectively and are all significant at $1 \%$ level of significance. This implies that $33 \%$ of their pooled expressed variation in the output of both the maize farmers with and without access to extension service in the study area. Maize farmers with and without access to extension training have regression coefficient of 0.985 and 0.166 . This indicates that maize output will 
increase at the rate of 0.985 as more extension services are rendered to the maize farmers, while output of the farmers without access to extension training will increase at rate of 0.166 as they apply more of the farming experience to maize production in the study area. From the mean efficiency of the farmers with and without access to extension training, which are 0.9638 and 0.9229 , it indicates that maize farmers with access to extension training are more efficient than maize farmers without access to extension training and invariably they had higher maize output compared to those maize farmers without access to extension training. These results are consistent with the findings of ${ }^{[3,10]}$.

Table 5: Maximum likelihood estimates for the parameters of the stochastic frontier production function for pooled of the farmers with and without extension contact

\begin{tabular}{|c|c|c|c|}
\hline Variable & Parameter & Model 2 & T-value \\
\hline \multicolumn{4}{|l|}{$\begin{array}{l}\text { General } \\
\text { (production function) }\end{array}$} \\
\hline Constant & $\beta_{0}$ & -0.2347 & 16.44 \\
\hline Labour used & $\beta_{1}$ & 0.1717 & $3.2751 *$ \\
\hline Farm size & $\beta_{2}$ & 0.2402 & $3.5171^{*}$ \\
\hline Seed quantity used & $\beta_{3}$ & 0.2793 & 0.2836 \\
\hline Fertilizer quantity & $\beta_{4}$ & 0.6968 & $7.6451^{*}$ \\
\hline Herbicide quantity used & $\beta_{5}$ & 0.1585 & 0.6346 \\
\hline $\begin{array}{l}\text { Inefficiency model } \\
\text { Constant }\end{array}$ & $\delta_{0}$ & 0.6077 & 0.8162 \\
\hline Family size & $\delta_{1}$ & 0.3773 & 1.3554 \\
\hline $\begin{array}{ll}\begin{array}{l}\text { Year of farming } \\
\text { experience }\end{array} & \\
\end{array}$ & $\delta_{2}$ & -0.2194 & $-2.2883 * *$ \\
\hline $\begin{array}{l}\text { Frequency of extension } \\
\text { contact }\end{array}$ & $\delta_{3}$ & $\begin{array}{c}-0.8718 \\
\end{array}$ & $-3.7070 *$ \\
\hline Educational level & $\delta_{4}$ & -0.1269 & $-8.0680 *$ \\
\hline $\begin{array}{l}\text { Number of types of } \\
\text { extension channel }\end{array}$ & $\delta_{5}$ & 0.3834 & 1.1331 \\
\hline \multicolumn{4}{|l|}{ Variance parameters } \\
\hline Sigma Squared & $\sigma^{2}$ & 0.4364 & 0.5836 \\
\hline Gamma & $\Gamma$ & 0.4364 & 0.3289 \\
\hline $\begin{array}{ll}\text { Log } & \text { Likelihood } \\
\text { Function } & \\
\end{array}$ & & 261.5 & \\
\hline
\end{tabular}

\section{Test of mean technical efficiency}

Here it was presumed that there is no significant difference between the mean technical efficiency of both farmers with and without extension contact. On the test of significant differences of mean technical efficiencies for large sample $(n>30)$. The result in the Table 6 shows the differences in the mean technical efficiencies of both contact (0.9138) and non-contact (0.5129) maize farmers in the study area.
The result indicates that significant difference exists between the mean technical efficiencies (TE) of contact and non-contact maize farmers with the mean difference of 0.4009 . Therefore, null hypothesis is rejected, while alternative hypothesis is accepted. This implies that maize farmers with extension contact are technically efficient than the non-contact maize farmers in the study area. The difference in their mean technical efficiencies may be due to efficient application of extension technologies available to the contact farmers to their various maize farm operations.

Table 6: Test of significant difference of mean technical efficiencies between the contact and non-contact maize farmers

\begin{tabular}{|l|l|l|l|}
\hline Item & Contact & Non-contact & Decision \\
\hline No of farmers & 111 & 70 & 181 \\
\hline Mean TE & 0.9138 & 0.5129 & Reject Ho \\
\hline
\end{tabular}
Efficiency

\section{CONCLUSION AND RECOMMENDATIONS}

The study concludes that larger percentage of the sampled maize farmers were aged, males were more involved in maize production compared to female farmers. The contact maize farmers received extension agent on different occasion. Maize farmers with extension contact received different training on different aspect of maize production. Farmers with extension contact were technically efficient than farmers without extension contact in the study area. The study therefore recommends the need to create more awareness on the roles of extension services in maize crop and general agricultural production among the farmers; and the authorities concerns with extension service delivery should improve on the frequency of extension contact in order to encourage farmers' participation in extension activities in the study area and rural communities in Nigeria at large.

\section{Acknowledgement: None}

Conflict of Interest: None 


\section{Source of Funding: None}

\section{REFERENCES}

1. Ajibefun LA. and Daramola,A.G. "Measurement and source of Technical Inefficiency in poultry Egg Production in Ondo State, Nigeria. Journal of Rural Economics and Development.1991, 13 (2): 85-94.

2. Awudu A and Richard F. Technical Efficiency during Economic Reform Nicaragua; Evidence from Farm Households Survey Data. Economics System. 2001, 25: 113-125.

3. Al-Shadiade A.N.H. Descriptive study of Training Needs for Men and Women Farmers in Semi Desert Areas of a case Study of South Jordan. World Applied Science Journal, 2007, 2 (1):12 - 21.

4. Battese G.E and T.J Coelli. "A model for Technical Inefficiency in a Stochastic Frontier production for panel Data. Empirical Economics. 1995, 20: 325-332.

5. Ejembi E.P. and Ejembi S.A. Farmers' assessment of the training and visit extension system in central Nigeria: Evidence from Barkin Ladi, Plateau State. 2006, Pp. 2.

6. Lawrence F. Salmen (SDV) Beneficiary Assessment from Agricultural Extension: A manual of Good practice. The World Bank Development Family: Agricultural knowledge and information system (AKIS). 2000, Pp. 11.

7. Mbise M. The impact of extension services on agricultural production: A case of maize in Ludewa District of Njombe Region, Tanzania. Ruforum working Document Series. 2016, No. 14 (4): 105-111.

8. Ogunfiditimi T.G. and Ewuola S.O. The synthesis of comparative Agricultural Extension system. Emm press Ltd, Ibadan Nig. 1995, Pg 42, 49, \&51

9. Pierre L. Performance of services: A framework to assess farm extension services. Paper prepared for presentation at the $11^{\text {th }}$ seminar of the EAAE (European Association of Agricultural Economists), The Future of Rural Europe in the Global Agric- Food System; Copenhagen, Denmark, August 24-27, 2005. Pp. 4\&5.

10. Seyoum E. T. G. E. Battese and E. M. Fleming. Technical Efficiency and Productivity of Maize producers in Easthern Ethiopia: A study of Farmers within and outside the Sasakawa Global 2000 Project". Agricultural Economics. 1998, 19: 34 - 48.

How to cite this article: Oluwole AJ, Segun AO, Bayonle RS et.al. Effect of extension training on technical efficiency of maize farmers in Ogbomoso Agricultural Zone of Oyo State, Nigeria. International Journal of Research and Review. 2021; 8(9): 210-217. DOI: https://doi. org/10.52403/ijrr.20210928 